\title{
Pregnancy- and lactation-associated osteoporosis with vertebral fractures: a systematic review
}

Ying Qian' ${ }^{1}$ Lei Wang ${ }^{2}$, Lili Yu ${ }^{3}$ and Weimin Huang ${ }^{2 *}$

\begin{abstract}
Background: To review, analyze and characterize the pregnancy and lactation-related osteoporosis (PLO) with vertebral fractures based on the extraction data in the previous studies.

Methods: A comprehensive literature search of electronic databases including the PubMed, Embase and Web of Science was conducted from January 1st,1990 to December 1st, 2020. The enrolled data were pooled to analyze the baseline characteristics, clinical features, risk factors and treatment options.

Results: A total of 65 articles with 338 cases were enrolled for data extraction. The enrolled cases aged from 19 to 47 years, with a mean value of 35.7 years old. The average body mass index (BMI) was $22.2 \mathrm{~kg} / \mathrm{m}^{2}$ ranged from 16.0 to $39.0 \mathrm{~kg} / \mathrm{m}^{2}$. Of the 173 cases, 149 cases with vertebral fractures occurred in the first pregnancy, 19 cases in the second pregnancy, four cases in the third pregnancy and one case in the fourth pregnancy. Up to 91.5\% of the back pain occurred within the last 3 months of pregnancy and the first 3 months after delivery. The most involved vertebral levels were L2, L1 and T12 accounting for $32.6 \%$ of all the fractures. The average fracture numbers were 4.4 levels per patient. The lumbar Z-scores were mostly recorded with a mean value of -3.2 ranged from -7.8 to 0 .

Conclusions: PLO with vertebral fractures is a rare clinical entity, which is more likely to occur in older and thinner pregnant women. Back pain is the clinical complaint and mostly occurs in the late pregnancy and early lactation periods. Most vertebral fractures appear in the first pregnancy but it can occur in any time of pregnancy. Thoracolumbar region is the mostly involved region. As compared with postmenopausal osteoporotic fractures, PLO usually has multiple levels fractures. Bisphosphonates are the most widely used treatment so far, however, many factors need to be taken into account to decide which drug to choose in PLO and further studies are necessary for clear recommendation in the future.
\end{abstract}

Keywords: Pregnancy, Lactation, Osteoporosis, Vertebral fractures, Systematic review

\section{Background}

Pregnancy- and lactation-associated osteoporosis (PLO) is a rare type of osteoporosis that often occurred during the late pregnancy and early lactation [1-4]. Epidemiological data on PLO are limited although previous study

${ }^{*}$ Correspondence: ever_23@163.com

2 Orthopaedic Department, 960 Hospital of People's Liberation Army, NO.25 Shifan Road, Jinan, Shandong 250031, People's Republic of China

Full list of author information is available at the end of the article has estimated that the prevalence was $4-8$ patients per million of population [5]. PLO mainly involves in vertebral body and hip [6-8]. Back pain is one of the most common clinical manifestation and many patients may suffer from vertebral fractures or even kyphosis $[9,10]$. PLO carries great physiological and psychological burdens to patients and has negative effects on quality of life and working ability. It was reported that the mean time for the PLO patients returned to work was more than 3 years [11]. original author(s) and the source, provide a link to the Creative Commons licence, and indicate if changes were made. The images or other third party material in this article are included in the article's Creative Commons licence, unless indicated otherwise in a credit line to the material. If material is not included in the article's Creative Commons licence and your intended use is not permitted by statutory regulation or exceeds the permitted use, you will need to obtain permission directly from the copyright holder. To view a copy of this licence, visit http://creativecommons.org/licenses/by/4.0/. The Creative Commons Public Domain Dedication waiver (http://creativeco mmons.org/publicdomain/zero/1.0/) applies to the data made available in this article, unless otherwise stated in a credit line to the data. 
Since the first report in 1955 by Nordin, many studies have reported this clinical entity [1-4, 6, 11-23]. Because of the relatively low incidence, most of the studies were case reports and case series, and the clinical features were systematically varied. The patients had experienced back pain differently. Pain can vary from mild to severe and the manifestations of PLO can be present in different trimester of pregnancy. Certain PLO cases occur in the first pregnancy and some occurred in the fourth pregnancy [24]. The patients may have potential risk factors like prior fractures history $[25,26]$, taking drugs affecting bone metabolism [27-29], smoking and family history of osteoporosis $[6,11,30]$. There is no specific department for PLO. Patients may have attended the Department of Endocrinology, Orthopedics or Obstetrics and Gynecology, however, due to the study limitations and poor awareness, many clinicians have imposing appropriate diagnostic delay and may result in poor prognosis [27].

In order to enhance the knowledge on PLO with vertebral fractures, a systematic review was conducted. We aimed to characterize the clinical manifestation, risk factors, fracture sites and treatment options of PLO based on a data extraction file.

\section{Methods}

\section{Search terms}

A comprehensive literature search of electronic databases including the PubMed, Embase and Web of Science was conducted on December 1st, 2020 to retrieve all articles reporting PLO. The search strategy utilized the following key terms: "Pregnancy OR pregnant OR lactation OR breastfeeding", "Osteoporosis OR osteoporotic", "Vertebra OR spine OR spinal OR lumbar OR thoracic OR thoracolumbar", "Fracture OR fractures". The search terms were simply contained in the words of the title and abstract of the Pubmed and Embase and in topic terms in the Web of Science. The cases reported in the early literature were seldom diagnosed by using Magnetic resonance imaging (MRI) for vertebral fractures, therefore we only included studies published after January 1st, 1990.

\section{Inclusion and exclusion criteria}

The inclusion and exclusion criteria of the studies were shown in the Table 1.

\section{Data extraction}

Data extraction process was referred to Cochrane Handbook [31]. The retrieved articles were examined and reviewed independently by two researchers. Duplicates were removed automatically by EndNote X8.1 and manually by comparing authors, titles and date of the publications. After the removal of duplicates, title, abstract and full text of articles were screened. Articles reporting the same cohort were also excluded. Then, the supplement search of the references in all the enrolled articles was performed. Data extraction of the selected articles was conducted by two authors using a standard table based on the Cochrane Handbook [31]. The population included was characterized by women affected by PLO and vertebral fractures, and the MRI imaging was used to identify these fractures. For those articles reporting case series, data extractions were performed only in those cases with vertebral fractures. Any disagreements were resolved by a third researcher. In order to unify the standard, the age at onset of symptoms and the height before pregnancy were recorded. Finally, the extracted data were systematically analyzed.

\section{Quality assessment}

Two reviewers independently assessed the quality of the included studies. Disagreements were settled down by discussion among authors. The Joanna Briggs Institute (JBI) critical appraisal checklist for case reports and case series were employed to evaluate the quality of the included studies [32]. There were eight questions in the checklist for case reports and ten questions in the checklist for case series, so the reviewers decided that the

Table 1 Study inclusion and exclusion criteria

\begin{tabular}{ll}
\hline Inclusion criteria & Exclusion criteria \\
\hline All articles on PLO published in English. & 1. Basic research. \\
& 2. Editorials, letters or meeting abstract. \\
& 3. Studies that could not found full-text. \\
& 4. Studies that provided too little valuable information to be used for analysis. \\
& 5. Vertebral fractures that had no direct connection with pregnancy or \\
occurred during pregnancy or lactation but having underlying diseases that & led to osteoporosis. \\
6. Studies on fractures other than vertebral.
\end{tabular}




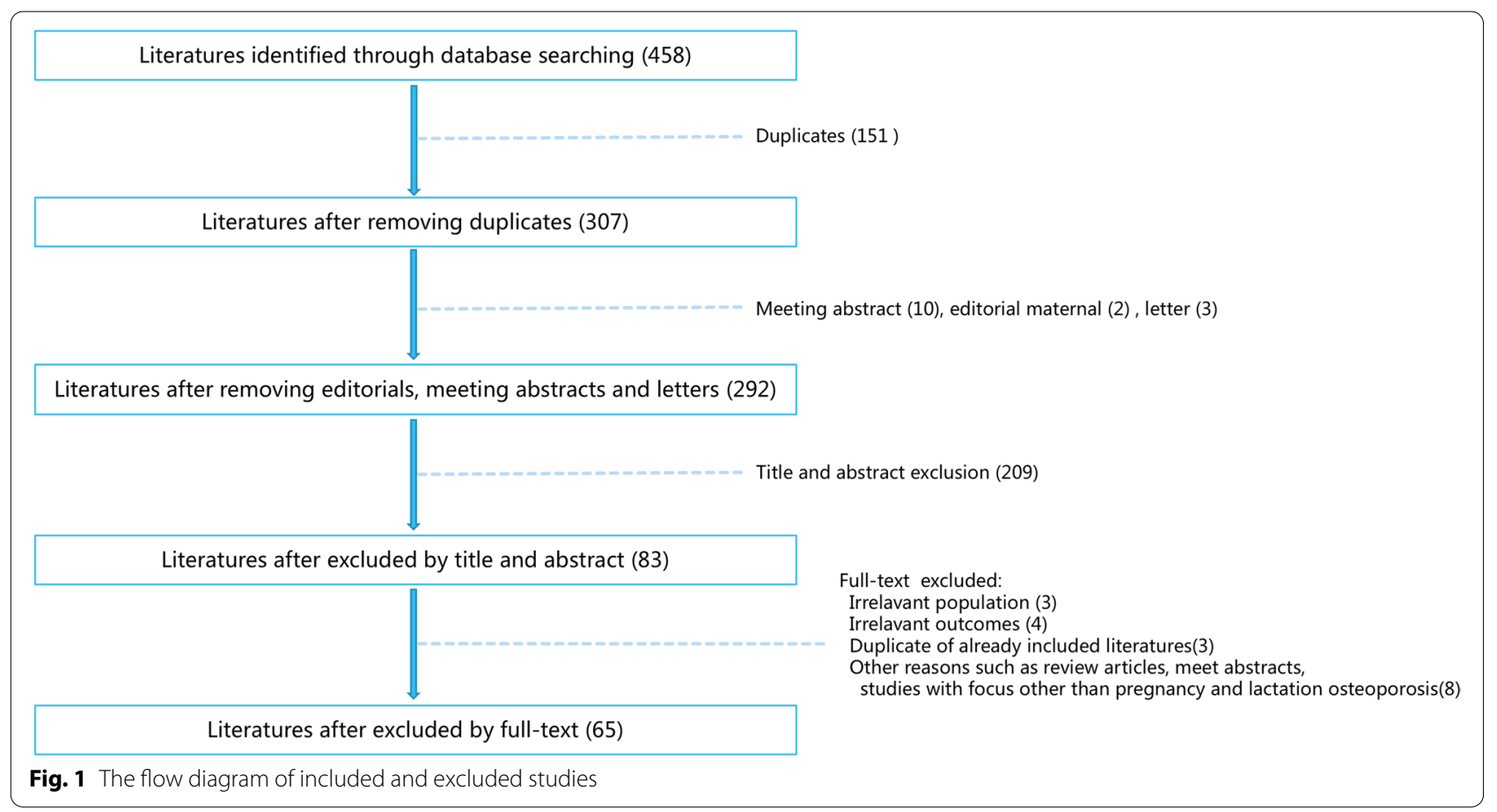

studies achieving adequate quality for inclusion should meet a minimum of $50 \%$ of the questions requiring a "yes" response.

\section{Results}

\section{Studies selection process}

At the initial, 458 articles were retrieved from the database searching, 307 of which remained after duplicates removed. After removing meeting abstract, editorial material and letters, 292 articles were obtained. Of these, 209 were excluded since they did not meet the inclusion criteria. After full text articles assessed for eligibility, another 18 articles were excluded. Finally, 65 articles with 338 cases were enrolled in this systematic review for further data extraction. The flow chart shown in Fig. 1 demonstrates the selection process in detail.

\section{Study characteristics}

Baseline characteristics are showed in Table 2. All the enrolled studies were case report and case series with the case number ranged from 1 to 107 patients. Overall the studies had achieved adequate quality for inclusion (Additional files 1 and 2). Kyvernitakis [1] reported the most cases numbered at 107 based on the German reference center for PLO and Laroche [2] reported the subsequent most cases numbered at 52 based on the French Society of Rheumatology. The number of articles published increased year by year, with 9 articles from 1991 to 2000, 13 articles from 2001 to 2010, and 43 articles from 2011 to 2020. The enrolled studies distributed globally with 34 studies in Europe, 17 studies in Asia, 5 studies in Australia, 5 studies in South America, 3 studies in North America and one study in Africa. Turkey had the highest number of PLO articles which 11 articles recorded, followed by Germany $(n=8)$, Italy $(n=7)$, and South Korea $(n=7)$.

\section{Baseline characteristics of included cases}

All the included PLO patients aged 19 to 47 years. A total of 191 cases documented the detailed age information with a mean age of 35.7 years. Of the 191 cases, 6 cases over 40 years old accounting for 3.1\%, 109 cases over 30 years old accounting for $57.1 \%, 29$ cases under 26 years old accounting for $15.2 \%$. The age distributions are illustrated in Fig. 2. The average height of the included cases is $164.2 \mathrm{~cm}$, ranged from $144 \mathrm{~cm}$ to $175 \mathrm{~cm}$. The body mass index (BMI) of 46 studies was calculated and documented with a mean value of $22.2 \mathrm{~kg} / \mathrm{m}^{2}$ ranged from $16.0 \mathrm{~kg} / \mathrm{m}^{2}$ to $39.0 \mathrm{~kg} / \mathrm{m}^{2}$. The BMI distributions of 98 individuals are showed in Fig. 3. The observed data showed that few PLO patients were obese and overweight. Furthermore, race information of 38 cases was documented, which was Caucasians $(n=26)$, Hans $(n=9)$, Manchu $(n=1)$, Fijian $(n=1)$ and Moroccan $(n=1)$.

\section{Clinical features}

A total of 173 cases had the information on number of pregnancy when vertebral fractures occurred, in whom 
Table 2 Characteristics and main findings of the included studies

\begin{tabular}{|c|c|c|c|c|c|c|c|c|}
\hline First author & $\begin{array}{l}\text { Published } \\
\text { year }\end{array}$ & Journal & No of Cases ${ }^{a}$ & Race & $\begin{array}{l}\text { Age at onset } \\
\text { (years, } \\
\text { mean } \pm \text { SD) }\end{array}$ & $\begin{array}{l}\text { Height } \\
(\mathrm{cm}, \\
\text { mean } \pm \text { SD) }\end{array}$ & $\begin{array}{l}\text { Weight } \\
(\text { kg, } \\
\text { mean } \pm \text { SD) }\end{array}$ & $\begin{array}{l}\mathrm{BMI} \\
\left(\mathrm{kg} / \mathrm{m}^{2},\right. \\
\text { mean } \pm \mathrm{SD})\end{array}$ \\
\hline Tuna [3] & 2020 & $\begin{array}{l}\text { Gynecol Endo- } \\
\text { crinol }\end{array}$ & $9 / 14$ & & 31 & & & 21.3 \\
\hline Hardcastle [6] & 2019 & Osteoporos Int & 10 & $\begin{array}{l}\text { 1Moroccan, } \\
\text { 9NA }\end{array}$ & 33 & & & 23.3 \\
\hline Scott [23] & 2019 & Osteoporos Int & 1 & Caucasian & 33 & 162 & 74 & 28.2 \\
\hline Ozturk [22] & 2019 & $\begin{array}{l}\text { Gynecol Endo- } \\
\text { crinol }\end{array}$ & 2 & & 33,28 & & & $27.4,22.6$ \\
\hline Gehlen [11] & 2019 & Clin Rheumatol & 20 & & 33.9 & & & 23.5 \\
\hline Zhu [33] & 2018 & Osteoporos Int & 2 & & 29 & & & \\
\hline Li [20] & 2018 & Clin Rheumatol & $10 / 12$ & $\begin{array}{l}\text { 9Han, 1Man- } \\
\text { chu }\end{array}$ & 31 & & & 21.5 \\
\hline Hong [34] & 2018 & Clin Endocrinol & 32 & & $31.3 \pm 2.6$ & & & $20.3 \pm 2.4$ \\
\hline Butscheidt [35] & 2018 & Osteoporos Int & $5 / 7$ & & 35 & & & 22.8 \\
\hline Taraktas [21] & 2018 & $\begin{array}{l}\text { Turk J Endo- } \\
\text { crinol Metab }\end{array}$ & 1 & & 22 & & & \\
\hline Yun [4] & 2017 & $\begin{array}{l}\text { Obstet Gynecol } \\
\text { Sci }\end{array}$ & 6 & & 32 & 164 & 57 & 21.1 \\
\hline Kyvernitakis [1] & 2017 & Osteoporos Int & 107 & & $39.5 \pm 6.0$ & $165.9 \pm 6.3$ & $63.5 \pm 11.1$ & $23.1 \pm 3.7$ \\
\hline Zhang [36] & 2017 & Medicine & 1 & & 23 & & & 21.2 \\
\hline Laroche [2] & 2017 & Osteoporos Int & 52 & & 27 & & & \\
\hline Ljuin [19] & 2017 & $\begin{array}{l}\text { Taiwan J Obstet } \\
\text { Gynecol }\end{array}$ & 1 & & 27 & 163 & 45 & 17.1 \\
\hline Pola [17] & 2016 & $\begin{array}{l}\text { J Biol Regul } \\
\text { Homeost } \\
\text { Agents }\end{array}$ & 1 & Caucasian & 33 & 167 & 60 & 21.5 \\
\hline $\begin{array}{l}\text { Krishnakumar } \\
\text { [37] }\end{array}$ & 2016 & $\begin{array}{l}\text { J Craniovert } \\
\text { Jun Spine }\end{array}$ & 2 & & 27,31 & & & \\
\hline Sánchez [18] & 2016 & $\begin{array}{l}\text { Clin Cases } \\
\text { Miner Bone } \\
\text { Metab }\end{array}$ & 2 & & 35,33 & 162,157 & & \\
\hline Grana [9] & 2016 & Pain Med & 1 & Caucasian & 31 & & & \\
\hline Gaudio [38] & 2016 & $\begin{array}{l}\text { Clin Cases } \\
\text { Miner Bone } \\
\text { Metab }\end{array}$ & 1 & & 38 & 167 & 54 & 19.4 \\
\hline Ekim [29] & 2016 & J Clin Anal Med & 1 & & 35 & 165 & 54 & 19.8 \\
\hline Polat [39] & 2015 & $\begin{array}{l}\text { Gynecol Endo- } \\
\text { crinol }\end{array}$ & 1 & & 23 & & & 24.0 \\
\hline $\begin{array}{l}\text { Hadgaonkar } \\
\text { [40] }\end{array}$ & 2015 & Asian Spine J & 1 & & 24 & & & \\
\hline Ozdemir [28] & 2015 & Osteoporos Int & 2 & & 34,36 & 168,162 & 62,59 & $21.9,22.5$ \\
\hline Kovacs [16] & 2015 & Osteoporos Int & $1 / 2$ & & 35 & 151 & 46 & 20.0 \\
\hline Grizzo [26] & 2015 & Calcif Tissue Int & 1 & Caucasian & 31 & 165 & 55 & 20.2 \\
\hline Zarattini [41] & 2014 & $\begin{array}{l}\text { Clin Cases } \\
\text { Miner Bone } \\
\text { Metab }\end{array}$ & 1 & Caucasian & 27 & 165 & 63 & 23.1 \\
\hline Takahashi [42] & 2014 & $\begin{array}{l}\text { Fukushima J } \\
\text { Med Sci }\end{array}$ & 1 & & 22 & 163 & 60 & 22.6 \\
\hline Obando [30] & 2014 & $\begin{array}{l}\text { J Clin Endo- } \\
\text { crinol Metab }\end{array}$ & 1 & Caucasian & 27 & 158 & 53 & 21.2 \\
\hline Raffaetà [43] & 2014 & $\begin{array}{l}\text { Clin Cases } \\
\text { Miner Bone } \\
\text { Metab }\end{array}$ & 2 & & 42,21 & 167 & 66 & 23.7 \\
\hline Ozturk [15] & 2014 & $\begin{array}{l}\text { J Obstet } \\
\text { Gynaecol }\end{array}$ & 2 & & 22,34 & & & \\
\hline
\end{tabular}


Table 2 (continued)

\begin{tabular}{|c|c|c|c|c|c|c|c|c|}
\hline First author & $\begin{array}{l}\text { Published } \\
\text { year }\end{array}$ & Journal & No of Cases ${ }^{a}$ & Race & $\begin{array}{l}\text { Age at onset } \\
\text { (years, } \\
\text { mean } \pm \text { SD) }\end{array}$ & $\begin{array}{l}\text { Height } \\
(\mathrm{cm}, \\
\text { mean } \pm \mathrm{SD})\end{array}$ & $\begin{array}{l}\text { Weight } \\
\text { (kg, } \\
\text { mean } \pm S D)\end{array}$ & $\begin{array}{l}\mathrm{BMI} \\
\left(\mathrm{kg} / \mathrm{m}^{2}\right. \\
\text { mean } \pm \mathrm{SD})\end{array}$ \\
\hline Baldane [44] & 2014 & $\begin{array}{l}\text { Turk FizTip } \\
\text { Rehabil Derg }\end{array}$ & 1 & & 35 & 155 & 45 & 18.7 \\
\hline Winarno [45] & 2014 & $\begin{array}{l}\text { Z Geburtsh } \\
\text { Neonatol }\end{array}$ & 1 & & 29 & 158 & 46 & 18.4 \\
\hline Terzi [10] & 2014 & BioMed Res Int & 1 & & 32 & & & \\
\hline Cook [46] & 2014 & $\begin{array}{l}\text { J Bone Miner } \\
\text { Res }\end{array}$ & 1 & Caucasian & 26 & 161 & 68 & 26.2 \\
\hline Scozzari [47] & 2014 & $\begin{array}{l}\text { Acta Medica } \\
\text { Mediterranea }\end{array}$ & 1 & & 19 & & & \\
\hline Lee [48] & 2013 & J Bone Metab & 1 & & 39 & 156 & 50 & 20.5 \\
\hline Bonacker [49] & 2013 & $\begin{array}{l}\text { Arch Orthop } \\
\text { Trauma Surg }\end{array}$ & 1 & & 40 & & & \\
\hline Lwamoto [13] & 2012 & $\begin{array}{l}\text { Ther Clin Risk } \\
\text { Manag }\end{array}$ & 1 & & 32 & 155 & 57 & 23.7 \\
\hline Adamidou [50] & 2012 & $\begin{array}{l}\text { Horm-Int J } \\
\text { Endocrinol } \\
\text { Metab }\end{array}$ & 1 & Caucasian & 40 & 158 & 56 & 22.4 \\
\hline Choe [51] & 2012 & $\begin{array}{l}\text { J Bone Miner } \\
\text { Metab }\end{array}$ & 3 & & $36,32,30$ & & & $20.6,27.1,19.4$ \\
\hline Stupar [52] & 2012 & Rheumatol Int & 1 & & 30 & 152 & 52 & 22.5 \\
\hline Lee [53] & 2011 & $\begin{array}{l}\text { J Back Muscu- } \\
\text { loskelet Rehabil }\end{array}$ & 1 & & 31 & 157 & 50 & 20.3 \\
\hline Mastaglia [25] & 2010 & Osteoporos Int & 1 & & 20 & & & \\
\hline Kim [54] & 2010 & $\begin{array}{l}\text { J Korean Neu- } \\
\text { rosurg Soc }\end{array}$ & 1 & & 35 & 150 & 42 & 18.7 \\
\hline Hellmeyer [55] & 2010 & $\begin{array}{l}\text { Gynecol Endo- } \\
\text { crinol }\end{array}$ & 1 & & 40 & 171 & 62 & 21.2 \\
\hline Tanriover [12] & 2009 & Spine J & 1 & Caucasian & 23 & 169 & 65 & 22.8 \\
\hline Jang [56] & 2009 & Rheumatol Int & 1 & & 30 & 163 & 52 & 19.6 \\
\hline Ofluoglu [57] & 2008 & Rheumatol Int & 1 & & 30 & 162 & 50 & 19.1 \\
\hline Stumpf [27] & 2007 & Adv Med Sci & 2 & & 32,41 & & & 19.0 \\
\hline Hellmeyer [58] & 2007 & $\begin{array}{l}\text { Exp Clin Endo- } \\
\text { crinol Diabet }\end{array}$ & 1 & & 28 & 158 & 46 & 18.4 \\
\hline O'Sullivan [59] & 2006 & Osteoporos Int & 10 & $\begin{array}{l}\text { 9Caucasian, } \\
\text { 1Fijian }\end{array}$ & 31 & & & 22.0 \\
\hline Bayram [60] & 2006 & $\begin{array}{l}\text { Joint Bone } \\
\text { Spine }\end{array}$ & 1 & & 37 & & & \\
\hline Allali [61] & 2005 & Clin Rheumatol & 1 & & 38 & & & \\
\hline Tran [62] & 2002 & Intern Med J & 3 & $\begin{array}{l}\text { 2Caucasian, } \\
\text { 1NA }\end{array}$ & $23,22,36$ & $157,170,160$ & $47,48,47$ & $19.1,16.6,18.2$ \\
\hline Peris [63] & 2002 & $\begin{array}{l}\text { Clin Exp Rheu- } \\
\text { matol }\end{array}$ & 5 & & 31 & 155 & 54 & 22.4 \\
\hline Yamaga [64] & 2000 & $\begin{array}{l}\text { Eur J Obstet } \\
\text { Gynecol } \\
\text { Reprod Biol }\end{array}$ & 1 & & 25 & & & \\
\hline Gregorio [65] & 2000 & Nutrition & 3 & 3Caucasian & $38,33,30$ & 155,151 & 56,47 & $23.3,20.5$ \\
\hline Anai [66] & 1999 & $\begin{array}{l}\text { J Obstet } \\
\text { Gynaecol Res }\end{array}$ & 2 & & 24,30 & 161,155 & 44,47 & $17.0,19.6$ \\
\hline Babbitt [24] & 1998 & J Clin Densitom & 1 & & 46 & 175 & 71 & 23.2 \\
\hline Smith [67] & 1995 & $\begin{array}{l}\text { QJM-Mon J } \\
\text { Assoc Physi- } \\
\text { cians }\end{array}$ & 16 & & 28 & & & \\
\hline $\begin{array}{l}\text { Yamamoto } \\
\text { [68] }\end{array}$ & 1994 & Calcif Tissue Int & 5 & & 30 & 153 & 57 & 24.3 \\
\hline
\end{tabular}


Table 2 (continued)

\begin{tabular}{|c|c|c|c|c|c|c|c|c|}
\hline First author & $\begin{array}{l}\text { Published } \\
\text { year }\end{array}$ & Journal & No of Cases ${ }^{a}$ & Race & $\begin{array}{l}\text { Age at onset } \\
\text { (years, } \\
\text { mean } \pm \text { SD) }\end{array}$ & $\begin{array}{l}\text { Height } \\
(\mathrm{cm}, \\
\text { mean } \pm \text { SD) }\end{array}$ & $\begin{array}{l}\text { Weight } \\
(\text { kg, } \\
\text { mean } \pm \text { SD) }\end{array}$ & $\begin{array}{l}\mathrm{BMI} \\
\left(\mathrm{kg} / \mathrm{m}^{2},\right. \\
\text { mean } \pm \mathrm{SD})\end{array}$ \\
\hline Rillo [69] & 1994 & Clin Rheumatol & 1 & & 25 & & & \\
\hline Blanch [70] & 1994 & Br J Rheumatol & 2 & 2Caucasian & 31,28 & & & \\
\hline Reid [71] & 1992 & Clin Endocrinol & 1 & Caucasian & 31 & & & \\
\hline
\end{tabular}

NA not available

$B M I$ body mass index

PLO Pregnancy- and lactation-associated osteoporosis

a PLO with vertebral fractures/total population included

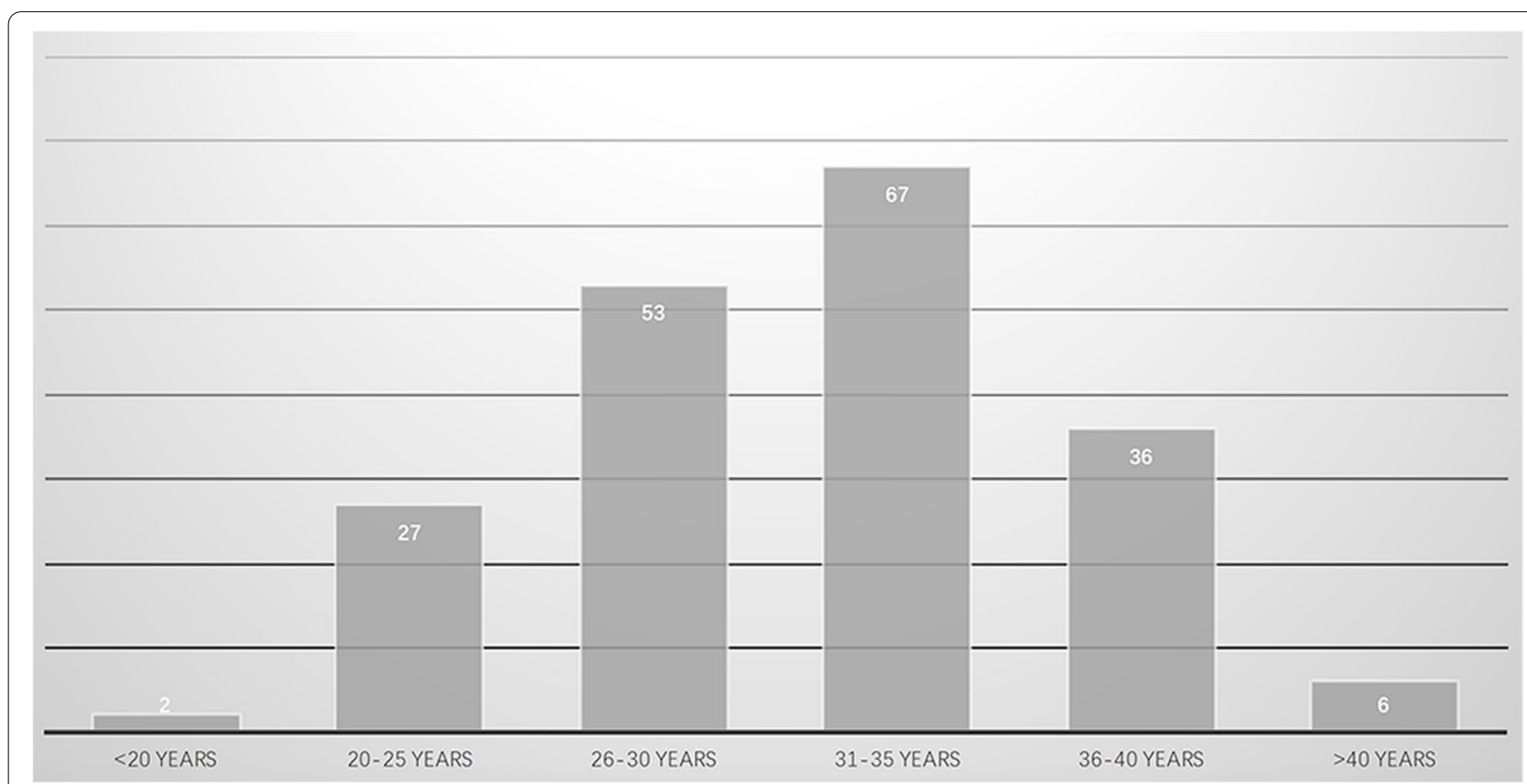

Fig. 2 The age distributions of the included population

149 cases were in primiparity, 19 cases were in the second pregnancy, 4 cases were in the third pregnancy and one case was in the fourth pregnancy. There were 108 cases clearly defined feeding manner, with 102 cases breastfeeding accounting for $94.4 \%$. Up to date, not much literature described the delivery way, in which there were vaginal delivery $(n=11)$ and cesarean delivery $(n=5)$.

All the 315 PLO patients with vertebral fractures were symptomized with back pain. The visual analogue score (VAS) were documented in 17 cases, of which all suffered from mild to severe pain and eight cases (47.1\%) complained of severe pain. The earliest time of symptom onset was determined at the 5 th month pregnancy, while the latest was at 9 months postpartum. Of the 82 cases with definite symptom onset time, 75 cases (91.5\%) with back pain occurred during the last 3 months of pregnancy and the first 3 months after delivery. The details of symptom onset time were shown in Fig. 4.

The risk factors associated with PLO were examined such as drug affecting bone metabolism, pre-partum fractures history, family history of osteoporosis, smoking and abnormal menstruation. A total of 59 patients had provided accurate medication history, of which 17 patients $(28.8 \%)$ had a history of oral anticoagulants such as heparin, low molecular weight heparin (LMWH) and four patients had a corticosteroids history. Of the 68 cases with pre-partum fractures history documented, 17 (25\%) cases were suffered from bone fractures before pregnancy. Regarding to family history of osteoporosis, of all the 172 cases with definite documentation, 57 patients $(33.1 \%)$ had positive family history of osteoporosis. Smoking status was recorded for 111 cases, in which 


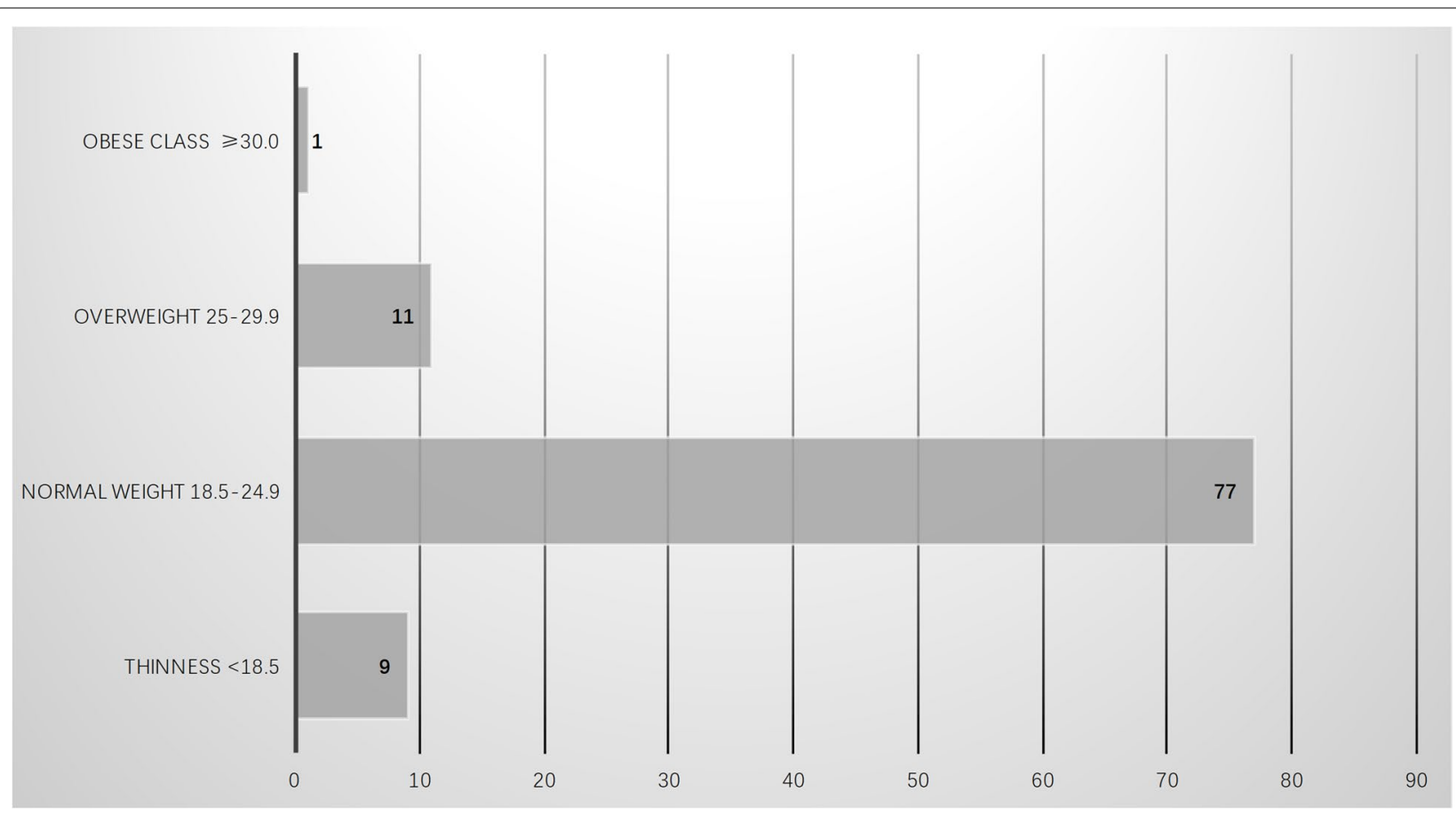

Fig. 3 The BMI distributions of the included population

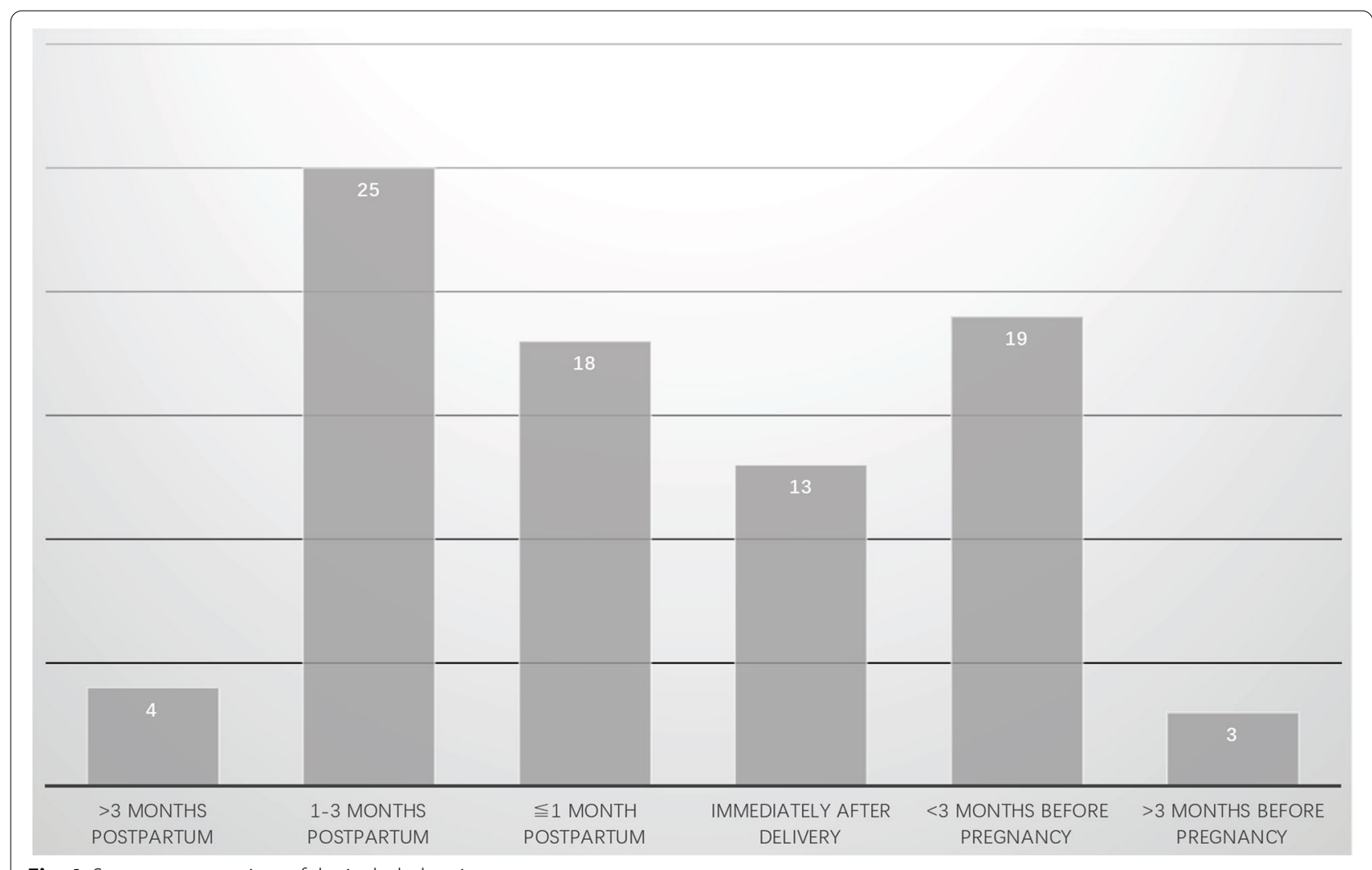

Fig. 4 Symptom onset time of the included patients 


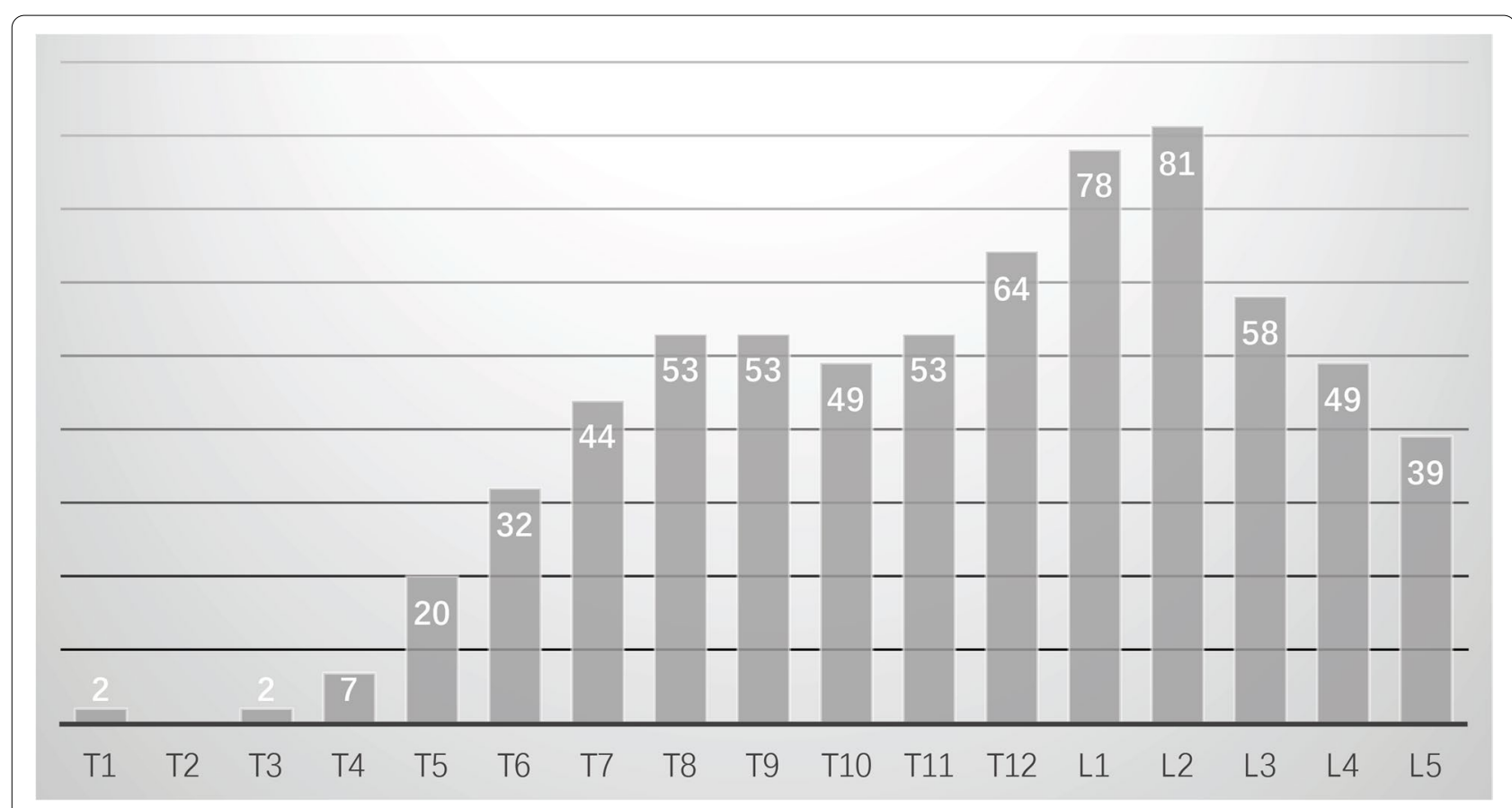

Fig. 5 The fractured site of the included population

24 cases $(21.6 \%)$ were smokers and ex-smokers. There were less menstruation records in the studies, 4 of 25 cases presenting irregular menses.

The studied articles have indicated variable rates of vertebral fractures. Fracture sites were described in 155 cases with 684 vertebral fractures and the average fracture was 4.4 vertebrae per patient. Most cases were suffered from multiple vertebral fractures with only 14 single segment vertebral fractures. As for specific fracture locations, the three most frequently involved vertebral fractures were L2, L1 and T12 (32.6\% of all the fractures). The number and site of fractured vertebrae are shown in Fig. 5.

Another important factor is Body mineral density (BMD). The BMD were measured by dual energy $\mathrm{x}$-ray absorptiometry (DXA) in the included studies and the BMD values of the enrolled cases were analyzed. $Z$-scores have been preferable used in the studies as compared to $T$-scores. The lumbar $Z$-scores were recorded in 123 cases in mean value of -3.2 ranged from -7.8 to 0 , while the hip $Z$-score were recorded in 122 cases with an average of -2.2 ranged from -5.5 to 0.9 . The lumbar $T$-scores were recorded in 51 cases with an average of -3.6 ranged from -6.5 to -1.3 , while the average of the hip T-scores of 47 cases was -2.5 (ranged from -6.5 to -0.2 ).

\section{Treatment options}

Different therapies that have been used in the management of PLO were documented in 108 cases. These supplementations included Calcium and vitamin D therapy $(n=7)$, bisphosphonates $(n=58)$, teriparatide $(n=24)$, denosumab $(n=10)$, calcitonin $(n=6)$, strontium ranelate $(n=2)$, simple rehabilitation without medication ( $n=2$, with mild symptoms) and vertebroplasty $(n=4$, with severe symptoms).

\section{Discussion}

The current study demonstrated that PLO is a rare clinical entity and distributed worldwide. To date, although more and more reports are available, the documentation of PLO is still very limited and its mechanism remains unclear. The pooled data revealed PLO is more likely appeared in those pregnant women of advanced maternal age. PLO is an age-related disease [1, 34]. Pregnant women in more than half of the cases were over 30 years.

Similar to postmenopausal osteoporosis, BMI may contribute to increasing risk of PLO. People who are obese or overweight have relatively higher risk of getting PLO.

In general, pregnant women experience calcium loss during the late pregnancy and postpartum lactation. BMD of pregnant women might be associated with pregnancy. In the study of Martina et al. (2010), the prospective changes of BMD with an ultrasonometry measurement in 59 pregnant women were observed. The 
results showed that BMD was reduced significantly in the second and third trimester of pregnancy [72]. This study indicated that osteopenia is a common condition in pregnant women. However, it is difficult and unethical to measure BMD of pregnant women by X-ray or CT. Contrarily, Lebel et al. (2014) studied the $T$-scores and $Z$-scores of the first 2 days after delivery in 132 pregnant women and found that both scores were within the normal limits regardless of age [73]. These findings indicated that the exact bone metabolism would be more sophisticated in pregnant women.

The pooled data also revealed that PLO may not appear in the first pregnancy. It might be occurred in the second, third or even fourth pregnancy. For patients with multiple pregnancies, PLO might appear in one of them, while other pregnancies were normal [24].

Fracture sites were analyzed in the present study. As compared with other osteoporotic vertebral fractures, PLO had more vertebrae involved. Only a few patients had a single level vertebral fracture. Thoracolumbar region is remained as the most affected area. MRI should be recommended to detect the conditions of thoracic and lumbar vertebrae if cases of missed diagnosis of the fractured vertebrae for the patients with suspected PLO occurred.

Despite its common occurrence, there is no standard clinical guideline for the treatment of PLO. Various kinds of drugs reported in the current reviews have been used in clinical practice for the treatment of PLO, such as bisphosphonates, teriparatide, denosumab and calcitonin. Bisphosphonates are the most used among the drugs. The safety of PLO therapy is always the major concern of clinicians and patients because of its longterm calcium deposits in bones. The use of bisphosphonates may develop adverse effects on both fetus and mother. However, no adverse effects of bisphosphonates on the pregnancy have been reported so far [20, $25,58]$. Calcitonin is more effective for acute pain relief $[62,66]$. Denosumab is a human monoclonal antibody and is effective for treatment of osteoporosis by inhibiting the activity of osteoclasts [19]. It has been reported denosumab had achieved satisfactory clinical efficacy when used independently [18] or combined with teriparatide as sequential therapy. Teriparatide is a human parathyroid hormone (PTH) formulation, which helps to regulate calcium metabolism $[19,34,51]$. It has a good prospect for clinic application due to its clinical efficacy and short half-life. However, potential side effect is the risk of bone tumors, which is related to the dosage and duration of treatment [19]. Many factors need to be taken into account to decide which drug to choose in PLO and new drugs and new treatment strategy should be explored in the future [74].

\section{Conclusion}

PLO is a rare clinical type of osteoporosis, which is more likely occur in older and thinner pregnant women. Back pain is a common clinical manifestation during the last 3 months of pregnancy and the first 3 months after delivery. Most PLO occurs in the first pregnancy but it may appear at different stages of pregnancy. Thoracolumbar region is the mostly affected region, however, as compared with postmenopausal osteoporotic fractures, PLO usually has multiple levels fractures. Presently, bisphosphonates are the most widely used treatment for PLO, however, many factors need to be taken into account to decide which drug to choose in PLO and further studies are necessary for clear recommendation in the future.

\section{Abbreviations}

PLO: Pregnancy and lactation-related osteoporosis; MRI: Magnetic resonance imaging; BMI: Body mass index; JBI: Joanna Briggs Institute; VAS: Visual analogue score; LMWH: Low molecular weight heparin; BMD: Body mineral density; DXA: Dual energy x-ray absorptiometry; PTH: Parathyroid hormone.

\section{Supplementary Information}

The online version contains supplementary material available at https://doi. org/10.1186/s12891-021-04776-7.

Additional file 1. The references about the included studies. Additional file 2. Quality assessment of the included studies. Additional file 3.

\section{Acknowledgements}

None

\section{Authors' contributions}

WH conceived the idea and contributed to design. WH and YQ ran the searches and extracted data. WH and LW assessed the methodological quality. $\mathrm{WH}$ and $\mathrm{LY}$ conducted the meta-analysis. $\mathrm{WH}$ and $\mathrm{YQ}$ wrote the manuscript. All authors approved the final version of the manuscript.

Funding

No funding was received for the conduction of this review.

Availability of data and materials

The datasets used and/or analyzed during the current study are available from the corresponding author on reasonable request.

\section{Declarations}

Ethics approval and consent to participate Not applicable.

Consent for publication

Not applicable.

Competing interests

The authors declare that they have no competing interests.

Author details

${ }^{1}$ Endocrinology Department, 960 Hospital of People's Liberation Army, NO.25 Shifan Road, Jinan, Shandong 250031, People's Republic of China. 
${ }^{2}$ Orthopaedic Department, 960 Hospital of People's Liberation Army, NO.25 Shifan Road, Jinan, Shandong 250031, People's Republic of China. ${ }^{3}$ Medical Information Department, 960 Hospital of People's Liberation Army, NO.25 Shifan Road, Jinan, Shandong 250031, People's Republic of China.

Received: 3 May 2021 Accepted: 6 October 2021 Published online: 03 November 2021

\section{References}

1. Kyvernitakis I, Reuter TC, Hellmeyer L, Hars O, Hadji P. Subsequent fracture risk of women with pregnancy and lactation-associated osteoporosis after a median of 6 years of follow-up. Osteoporosis Int. 2018;29:135-42.

2. Laroche M, Talibart M, Cormier C, Roux C, Guggenbuhl P, Degboe Y. Pregnancy-related fractures: a retrospective study of a French cohort of 52 patients and review of the literature. Osteoporosis Int. 2017;28:3135-42.

3. Tuna F, Akleylek C, Ozdemir H, Demirbag Kabayel D. Risk factors, fractures, and management of pregnancy-associated osteoporosis: a retrospective study of 14 Turkish patients. Gynecol Endocrinol. 2020;36:238-42.

4. Yun KY, Han SE, Kim SC, Joo JK, Lee KS. Pregnancy-related osteoporosis and spinal fractures. Obstet Gynecol Sci. 2017;60:133-7.

5. Smith R, Stevenson JC, Winearls CG, Woods CG, Wordsworth BP. Osteoporosis of pregnancy. Lancet. 1985;1:1178-80

6. Hardcastle SA, Yahya F, Bhalla AK. Pregnancy-associated osteoporosis: a UK case series and literature review. Osteoporos Int. 2019;30:939-48.

7. Hadji P, Boekhoff J, Hahn M, Hellmeyer L, Hars O, Kyvernitakis I. Pregnancy-associated transient osteoporosis of the hip: results of a casecontrol study. Arch Osteoporos. 2017;12:6.

8. Paoletta M, Moretti A, Liguori S, Bertone M, Toro G, Iolascon G. Transient osteoporosis of the hip and subclinical hypothyroidism: an unusual dangerous duet? Case report and pathogenetic hypothesis. BMC Musculoskelet Disord. 2020;21:6.

9. Grana E, Invernizzi M, Baricich A, Viscontini GS, Cisari C. A rare cause of Back pain during pregnancy and lactation: management and treatment. Pain Med. 2016;17:1382-5.

10. Terzi R, Terzi H, Ozer T, Kale A. A rare cause of postpartum low Back pain: pregnancy- and lactation-associated osteoporosis. Biomed Res Int. 2014;1-3.

11. Gehlen M, Lazarescu AD, Hinz C, Schwarz-Eywill M, Pfeifer M, Balasingam $\mathrm{S}$, et al. Long-term outcome of patients with pregnancy and lactationassociated osteoporosis (PLO) with a particular focus on quality of life. Clin Rheumatol. 2019;38:3575-83.

12. Tanriover MD, Oz SG, Sozen T, Kilicarslan A, Guven GS. Pregnancy- and lactation-associated osteoporosis with severe vertebral deformities: can strontium ranelate be a new alternative for the treatment? Spine J. 2009;9:e20-4.

13. Iwamoto J, Sato Y, Uzawa M, Matsumoto H. Five-year follow-up of a woman with pregnancy and lactation-associated osteoporosis and vertebral fractures. Therap Clin Risk Manag. 2012;8:195-9.

14. Kovacs CS. Osteoporosis presenting in pregnancy, puerperium, and lactation. Curr Opin Endocrinol Diabetes Obes. 2014;21:468-75.

15. Ozturk C, Atamaz FC, Akkurt H, Akkoc Y. Pregnancy-associated osteoporosis presenting severe vertebral fractures. J Obstet Gynaecol Res. 2014;1:288-92.

16. Kovacs CS, Ralston SH. Presentation and management of osteoporosis presenting in association with pregnancy or lactation. Osteoporosis Int. 2015:26:2223-41.

17. Pola E, Colangelo D, Nasto LA, Pambianco V, Autore G, Formica VM, et al. Pregnancy-associated osteoporosis (PAO) with multiple vertebral fragility fractures: diagnosis and treatment in a young primigravid woman. J Biol Regul Homeost Agents. 2016;30:153-8.

18. Sanchez A, Zanchetta MB, Danilowicz K. Two cases of pregnancy-and lactation-associated osteoporosis successfully treated with denosumab. Clin Cases Miner Bone Metab. 2016;13:244-6.

19. Ijuin A, Yoshikata H, Asano R, Tsuburai T, Kikuchi R, Sakakibara H. Teriparatide and denosumab treatment for pregnancy and lactation-associated osteoporosis with multiple vertebral fractures: a case study. Taiwan J Obstet Gynecol. 2017;56:863-6.
20. Li LJ, Zhang J, Gao P, Lv F, Song YW, Chang XY, et al. Clinical characteristics and bisphosphonates treatment of rare pregnancy-and lactation-associated osteoporosis. Clin Rheumatol. 2018;37:3141-50.

21. Taraktas A, Unlu Ozkan F, Illeez OG, Kulcu DG, Aktas I. Pregnancy-associated osteoporosis: long-term follow-up of a patient with two pregnancies. Turk J Endocrinol Metab. 2018;22:50-3.

22. Ozturk G, Akpinar P, Karamanlioglu AD, Ozkan FU, Aktas I. Pregnancyrelated osteoporotic vertebral compression fractures in two patients treated with low-molecular-weight heparin during pregnancy: case reports. Gynecol Endocrinol.2019;1:46-50.

23. Scott D, Shore-Lorenti C, Ebeling PR. Multiple vertebral compression fractures after sleeve gastrectomy and a subsequent pregnancy: a case report. Osteoporos Int. 2019:30:2151-4.

24. Babbitt AM. Post-pregnancy osteoporosis (PPO) - a case study. J Clin Densitom. 1998;1:269-73.

25. Mastaglia SR, Watman NP, Oliveri B. Intravenous bisphosphonate treatment and pregnancy: its effects on mother and infant bone health. Osteoporos Int. 2010;21:1959-62.

26. Grizzo FM, da Silva MJ, Pinheiro MM, Jorgetti V, Carvalho MD, Pelloso SM. Pregnancy and lactation-associated osteoporosis: bone Histomorphometric analysis and response to treatment with Zoledronic acid. Calcif Tissue Int. 2015;97:421-5.

27. Stumpf UC, Kurth AA, Windolf J, Fassbender WJ. Pregnancy-associated osteoporosis: an underestimated and underdiagnosed severe disease. A review of two cases in short- and long-term follow-up. Adv Med Sci. 2007;52:94-7.

28. Ozdemir D, Tam AA, Dirikoc A, Ersoy R, Cakir B. Postpartum osteoporosis and vertebral fractures in two patients treated with enoxaparin during pregnancy. Osteoporos Int. 2015;26:415-8.

29. Ekim AA, Eroglu P. Postpartum osteoporosis and thoracic vertebral fracture in a patient treated with heparin during pregnancy. J Clin Anal Med. 2016;7:154-7.

30. Campos-Obando N, Oei L, Hoefsloot LH, Kiewiet RM, Klaver CC, Simon ME, et al. Osteoporotic vertebral fractures during pregnancy: be aware of a potential underlying genetic cause. J Clin Endocrinol Metab. 2014;99:1107-11.

31. Nasser M. Cochrane handbook for systematic reviews of interventions. Am. J. Public Health. 2020;110:753-4.

32. Moola SMZ, Sears K, Sfetcu R, Currie M, Lisy K. Systematic reviews of etiology and risk. In: Aromataris E, Munn Z, editors. Joanna Briggs Institute Reviewer's Manual. The Joanna Briggs Institute; 2016. Available from https://reviewersmanual.joannabriggs/org/.

33. Zhu JJ, Mahendran D, Lee MH, Seah J, Fourlanos S, Varadarajan S, Ghasem-Zadeh A, Maclsaac RJ, Seeman E. Systemic mastocytosis identified in two women developing fragility fractures during lactation. Osteoporosis Int. 2018;29:1671-4.

34. Hong N, Kim JE, Lee SJ, Kim SH, Rhee Y. Changes in bone mineral density and bone turnover markers during treatment with teriparatide in pregnancy- and lactation-associated osteoporosis. Clin Endocrinol. 2018;88:652-8.

35. Butscheidt S, Delsmann A, Rolvien T, Barvencik F, Al-Bughaili M, Mundlos $\mathrm{S}$, Schinke T, Amling M, Kornak U, Oheim R. Mutational analysis uncovers monogenic bone disorders in women with pregnancy-associated osteoporosis: three novel mutations in LRP5, COL1A1, and COL1A2. Osteoporosis Int. 2018;29:1643-51.

36. Zhang M, Chen P, Li B, Du J, Pan T, Chen J. Approach to the patient with pregnancy and lactation-associated osteoporosis: A case report and a review of the literature. Medicine (Baltimore). 2017;96:e8671.

37. Krishnakumar R, Kumar AT, Kuzhimattam MJ. Spinal compression fractures due to pregnancy-associated osteoporosis. 2017;1:133-7.

38. Gaudio A, Fiore CE. Successful neridronate therapy in pregnancy-associated osteoporosis. Clin. Cases Miner. Bone Metab. 2016;13:241-3.

39. Polat SB, Evranos B, Aydin C, Cuhaci N, Ersoy R, Cakir B. Effective treatment of severe pregnancy and lactation-related osteoporosis with teriparatide: case report and review of the literature. Gynecol. Endocrinol. 2015;31:522-5.

40. Hadgaonkar S, Shah KC, Bhatt H, Shyam A, Sancheti P. Post Pregnancy Severe Spinal Osteoporosis with Multiple Vertebral Fractures and Kyphoscoliosis in a Multigravida: A Rare Case with Management. Asian Spine J. 2015;9:625-8 
41. Zarattini G, Buffoli P, Isabelli G, Marchese M. Pregnancy-associated osteoporosis with seven vertebral compression fractures, a case treated with strontium ranelate. Clin Miner bone Metab. 2014;11:139-41.

42. Takahashi N, Arai I, Kayama S, Ichiji K, Fukuda H, Handa J, Konno S. Fouryear follow-up of pregnancy-associated osteoporosis: a case report. Fukushima J Med Sci. 2014;60:175-80.

43. Raffaeta G, Mazzantini M, Menconi A, Bottai V, Falossi F, Celauro I, Guido G. Osteoporosis with vertebral fractures associated with pregnancy: two case reports. 2014:1:139-41.

44. Baldane S, Ipekci S, Sahin F, Gul Baldane E, Karabagli P, Kebapcilar L. Subclinical Celiac Disease Presented with Postpartum Low Back Pain Case Report. Turk Fiz Tip Rehabil Derg. 2015;61:175-8.

45. Winarno AS, Kyvernitakis I, Hadji P. Successful Treatment of 1-34 Parathyroid Hormone (PTH) after Failure of Bisphosphonate Therapy in a Complex Case of Pregnancy Associated Osteoporosis and Multiple Fractures. Z Geburtsh Neonat. 2014;218:171-3.

46. Cook FJ, Mumm S, Whyte MP, Wenkert D. Pregnancy-associated osteoporosis with a heterozygous deactivating LDL receptor-related protein 5 (LRP5) mutation and a homozygous methylenetetrahydrofolate reductase (MTHFR) polymorphism. J Bone Miner Res. 2014;29:922-8.

47. Scozzari F, Aronica GL, Seidita A, Taormina G, di Stefano L, D'Alcamo A, Carta M, Adragna F, Nugara G, Enna C, Mansueto P. OSTEOPOROSIS IN PREGNANCY: A CASE REPORT AND REVIEW OF THE LITERATURE. Acta Medica Mediterr. 2014;30:115-20.

48. Lee SH, Hong MK, Park SW, Park HM, Kim J, Ahn J. A case of teriparatide on pregnancy-induced osteoporosis. J Bone Metab. 2013;20:111-4.

49. Bonacker J, Janousek M, Krober M. Pregnancy-associated osteoporosis with eight fractures in the vertebral column treated with kyphoplasty and bracing. Case Rep. 2014;1:173-9.

50. Lampropoulou-Adamidou K, Trovas G, Stathopoulos IP, Papaioannou NA. Case Report: Teriparatide treatment in a case of severe pregnancy -and lactation- associated osteoporosis. Horm-Int J Endocrinol Metab. 2012;11:495-500.

51. Choe EY, Song JE, Park KH, Seok H, Lee EJ, Lim SK, Rhee Y. Effect of teriparatide on pregnancy and lactation-associated osteoporosis with multiple vertebral fractures. J Bone Miner Metab. 2014;1:596-601.

52. Vujasinovic Stupar N, Pejnovic N, Markovic L, Zlatanovic M. Pregnancy-associated spinal osteoporosis treated with bisphosphonates: long-term follow-up of maternal and infants outcome. Rheumatol Int. 2012;32:819-23.

53. Lee $J$ H, Lee $\mathrm{SH}$. Multiple vertebral compression fractures associated with post partum osteoporosis. J Back Musculoskelet Rehabil. 2011;24:117-21.

54. Kim HW, Song JW, Kwon A, Kim IH. Percutaneous Vertebroplasty for Pregnancy-Associated Osteoporotic Vertebral Compression Fractures. J Korean Neurosurgical Soc. 2010;47:399-402.

55. Hellmeyer L, Boekhoff J, Hadji P. Treatment with teriparatide in a patient with pregnancy-associated osteoporosis. Gynecol Endocrinol. 2010;26:725-8.

56. Jang JY, Lee JG, Jeong IK, Ahn KJ, Chung HY, Yang HI, Lee SH. A case of post-pregnancy osteoporosis combined with ankylosing spondylitis. Rheumatol Int. 2009;29:1359-62.

57. Ofluoglu O, Ofluoglu D. A case report: pregnancy-induced severe osteoporosis with eight vertebral fractures. Rheumatol Int. 2008;29:197-201.
58. Hellmeyer L, Kuehnert M, Ziller V, Schmidt S, Hadji P. The use of i. v. bisphosphonate in pregnancy-associated osteoporosis - Case study. Exp Clin Endocrinol Diabet. 2007;115:139-42.

59. O'Sullivan SM, Grey AB, Singh R, Reid IR. Bisphosphonates in pregnancy and lactation-associated osteoporosis. Osteoporosis Int. 2006;17:1008-12.

60. Bayram S, Ozturk C, Sivrioglu K, Aydinli U, Kucukoglu S. Kyphoplasty for pregnancy-associated osteoporotic vertebral fractures. Joint Bone Spine. 2006;73:564-6.

61. Allali F, Guedirra N, Hajjaj-Hassouni N. A case of post-pregnancy osteoporosis-related spinal fractures in association with ankylosing spondylitis. Clin Rheumatol. 2005;24:435-6.

62. Tran HA, Petrovsky N. Pregnancy-associated osteoporosis with hypercalcaemia. Intern Med J. 2002;32:481-5.

63. Peris P, Guanabens N, Monegal A, Pons F, de Osaba MJM, Ros I, MunozGomez J. Pregnancy associated osteoporosis: The familial effect. Clin Exp Rheumatol. 2002;20:697-700.

64. Yamaga A, Taga M, Takahashi T, Shirai T. A case of postpregnancy osteoporosis. Eur J Obstet Gynecol Reprod Biol. 2000;88:107-9.

65. Di Gregorio S, Danilowicz K, Rubin Z, Mautalen C. Osteoporosis with vertebral fractures associated with pregnancy and lactation. Nutrition. 2000;16:1052-5.

66. Anai T, Tomiyasu T, Arima K, Miyakawa I. Pregnancy-associated osteoporosis with elevated levels of circulating parathyroid hormone-related protein: a report of two cases. J Obstet Gynecol Res. 1999;25:63-7.

67. Smith R, Athanasou NA, Ostlere SJ, Vipond SE. Pregnancy-associated osteoporosis. QJM-Mon. J Assoc Physicians. 1995;88:865-78.

68. Yamamoto N, Takahashi HE, Tanizawa T, Kawashima T, Endo N. BONEMINERAL DENSITY AND BONE HISTOMORPHOMETRIC ASSESSMENTS OF POSTPREGNANCY OSTEOPOROSIS - A REPORT OF 5 PATIENTS. Calcif Tissue Int. 1994;54:20-5.

69. Rillo OL, Di Stefano CA, Bermudez J, Maldonado Cocco JA. Idiopathic osteoporosis during pregnancy. Clin Rheumatol. 1994;13:299-304.

70. Blanch J, Pacifici R, Chines A. Pregnancy-associated osteoporosis: report of two cases with long-term bone density follow-up. Br J Rheumatol. 1994;33:269-72.

71. Reid IR, Wattie DJ, Evans MC, Budayr AA. POST-PREGNANCY OSTEOPOROSIS ASSOCIATED WITH HYPERCALCEMIA. Clin Endocrinol. 1992;37:298-303.

72. Della Martina M, Biasioli A, Vascotto L, Rinuncini D, Menegato AA, Liva S, Londero AP, Driul L, Marchesoni D Bone ultrasonometry measurements during pregnancy. Arch Gynecol Obstet. 2010;281:401-7.

73. Elstein D, Mishukov Y, Babchenko L, Samueloff A, Zimran A, Lebel E. BONE MINERAL DENSITY IN GRAVIDA: EFFECT OF PREGNANCIES AND BREASTFEEDING IN WOMEN OF DIFFERING AGES AND PARITY. Osteoporosis Int. 2014;25:S355-S356.

74. Iolascon G MA, Toro G, Gimigliano F, Liguori S, Paoletta M. Pharmacological Therapy of Osteoporosis: What's New?. Clin Interv Aging. 2020;15:485-91.

\section{Publisher's Note}

Springer Nature remains neutral with regard to jurisdictional claims in published maps and institutional affiliations.
Ready to submit your research? Choose BMC and benefit from:

- fast, convenient online submission

- thorough peer review by experienced researchers in your field

- rapid publication on acceptance

- support for research data, including large and complex data types

- gold Open Access which fosters wider collaboration and increased citations

- maximum visibility for your research: over $100 \mathrm{M}$ website views per year

At BMC, research is always in progress.

Learn more biomedcentral.com/submissions 